\title{
Archiving and Re-using Qualitative and Qualitative Longitudinal Data in Slovenia
}

by Janez Stebe, Jože Hudales, Boris Kragelj'

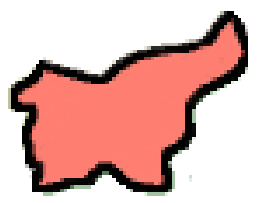

\section{Abstract}

This report starts from recognition that the archiving of qualitative raw materials that achieved a status of national cultural heritage, has been part of long established and well elaborated Slovenian national policy on preserving historical materials of national importance. A well established network of regional and national museums and archives operates a service of preservation, and of access for scientific purposes. On the other hand, despite a rich and flourish-

ing tradition of academic (and even private) qualitative research in Slovenia, in most cases all that remains after a project is finished is a research report. Still, besides official traditional archives and museums, there is a range of topic-specific public qualitative data resources, e.g. archives of Slovenian Radio and Television, and some emerging infrastructure for preserving the qualitative data originating from social science research projects (ETNOINFOLAB [http://www. etnoinfolab.org/]). Qualitative longitudinal resources for re-use were identified with similar problems as are found elsewhere. In conclusion we observed that the problems of qualitative data archiving are not insurmountable, as generally there is willingness, and much valuable material identified. International and national collaboration could help in optimising resources allocation, and an explicit national policy on data archiving would be a prerequisite for future success.

Keywords: qualitative data, qualitative longitudinal research, oral history, archiving, data sharing, Slovenia

\section{Introduction to report for Slovenia}

The state of qualitative data archiving and sharing in Slovenia ${ }^{2}$ is found to be mixed: on one hand, there is an organised network of well operated national archives and museums under state patronage, systematically preserving what remains of Slovenian historical national heritage; on the other hand, there are numerous independent, unrelated, and dispersed research groups and traditions outside of direct state regulation (e.g. university research

\section{the OECD (2007) Declaration on Open}

\section{Access is on the national priority list}

centres, private research institutes, marketing research agencies) producing a variety of original qualitative data collected for different purposes that lack any form of systematic preservation.

After consulting officials and public documents at the Slovenian Research Agency $(A R R S)^{3}$ and Ministry of Higher Education, Science and Technology (MVZT) ${ }^{4}$ we have not identified any national policies governing the archiving and sharing of qualitative research data produced by public or private organisations. Also, to date, we are not aware of any feasibility studies for qualitative data archiving, outside of the state owned and managed national archives and museums. Nevertheless, there is a sign of willingness from the MVZT to regulate the area of public domain scientific data sharing and reuse in general, following the principles of OECD Declaration on Open Access, of which Slovenia just recently become a full member. 
The archiving of the materials directly important to Slovenian national cultural heritage follow a well elaborated national policy on preserving historical materials of national importance. These qualitative data materials are stored by following strictly defined archiving procedures, well established international standards, and clear policy directions for preserving, archiving and sharing. These materials are of potential interest for various aims of qualitative research. They are available to the public under certain legal rules for their access and re-use . $^{5}$

Despite the fact that a centrally coordinated and standardised professional documentation (information) system is missing, the network of Slovenian museums is currently establishing a national project for the registering of movable cultural heritage, which will finally bring all their collections systematically together, in one place, with a single information service point. Slovenian museums are also following the Convention for the Safeguarding of the Intangible Cultural Heritage (ICH - 2003): they are systematically documenting oral tradition, traditional crafts and skills, knowledge and praxis connected with natural environment, living heritage, life stories in the form of oral histories, etc. as the mainspring of Slovenian cultural diversity.

On the other hand, similarly organized initiatives of archiving are widely missing among state-independent producers of qualitative data: e.g. private, non-government, or scientific research organisations that continuously generate original qualitative data as part of their research projects. In this particular research arena any form of regulation of qualitative data preservation, archiving and sharing for the purpose of its reuse is almost non-existent. The culture of qualitative data archiving and sharing, as part of the research culture, is estimated to be rather low, with little awareness of the potential of data sharing and archiving for its reuse. At best, it is in its early stages, with growing awareness of the richness and value of qualitative data but missing action for its systematic management.

When one of researchers (FSD) contacted for the purpose of this report was asked about concrete experiences of re-use of original material from the qualitative studies, only few could be imagined. These few cases are based on the involvement of a researcher who is willing to make materials accessible from his own past research projects, and make the data available to a new research team. Another example mentioned (MEMO) was about partner research agencies sharing their already available qualitative resources for their common projects. More typical were negative experiences, such as when a researcher would be willing to share the original material from past research projects with colleagues, but it proved to be impossible simply because the data were not properly preserved. As a general practice, the extent of qualitative data preservation here depends on researcher's own standards rather than any established organisational or institutional guidelines. The most common way of preserving qualitative data, if done at all, is by keeping the raw materials in the form in which they were originally collected, or in the form in which the analysis was concluded (FSD, FDV (Faculty of Social Sciences), MEMO, ARAGON). Even in the highest profile research studies, usually there is no systematic or institutionally regulated data preservation policy: raw materials are dispersed between offices and homes without specially designated spaces for their storage.

Such non-systematic preservation means that qualitative data collections often lack methodological and contextual details (study and data documentation, metadata) of the process of data collection that are much needed for judging the reliability and validity of the original data, and the possibility of its reconstruction for the purpose of re-use ${ }^{6}$.
Accounting also for the variety of mixed data formats as one of the most commonly mentioned problems of qualitative data, ranging from handwritten notes, audio and video files, to word processor transcripts, which are not consistent either between or within a single qualitative study, it is often felt that reconstruction of the original research framework and its organisation for the purpose of re-analysis is too challenging a task (FSD).

In sum, an overriding estimate across the research community indicates that original qualitative research materials are very hard to reach in a form suitable for reuse, either because they were not properly preserved, or because relevant metadata information is missing. Agreement from funder agencies as research commissioners, and ethical concerns regarding the privacy of participants, are often mentioned issues that additionally prevent further data exploitation (FSD, FDV MEMO, ARAGON). Considering the fact that secondary data are rarely completely appropriate to address a new research problem, starting a new process of qualitative data collection often still seems to be the option preferred over considering the possibilities for reuse of existing qualitative data resources. However, the prospects are becoming more optimistic: the OECD (2007) Declaration on Open Access is on the national priority list. The aim is to build relevant national policies for the long-term securing of data resources from publically funded research, and to glean examples of good practice from other countries as the basis for organising qualitative data resources in Slovenia in the future.

\section{Existing qualitative archiving infrastructure in Slovenia}

The existing qualitative archiving infrastructure in Slovenia can be divided into three distinct segments with respect to the content of its holdings (subjects, methods and data formats covered). These segments range from (A) several centralised, highly regulated and state managed national archives, (B) more or less well organised but devolved topic-specific qualitative data collections to be found in particular public archives and museums, and (C) loosely managed archiving facilities preserving original qualitative data production, collected for the purpose of genuine social science research projects.

\section{A. State (national) archives}

A range of archives run under state control with management and funding provided directly by the government of the Republic of Slovenia ${ }^{7}$. They all share the same competences and fall under the same jurisdiction. They are managed through one central National Archive of the Republic of Slovenia and several additional regional archives that cover their particular geographical areas.

They hold various original resources about the life of institutions, state, society and individuals in Slovenia preserved in the form of written, drawn, printed, photographed or otherwise documented archive materials that are estimated to be of permanent importance for Slovenian national cultural and historical heritage: historical documents on parchment, paper, film, and magnetic or optical data holdings, witnessing important information about the nature, objects, places, phenomena and people relevant to Slovenian national history and contemporary life (e.g., certificates, birth and death records, census data, cadastral registers and maps, and other personal data collections).

These qualitative data materials are preserved and used for national research purposes and historical evidence, as well as for administrative and jurisdiction purposes. Recently there has been a strong initiative to convert them into electronic format and provide them online $e^{8}$. There is also a strong emerging initiative to make these materials available to 
the public in digital form through an online service: some parts of the archive are already served electronically?.

All materials of these archives are carefully selected and professionally preserved following well-established (international) rules and procedures that are shared by all state archives ${ }^{10}$. Some of these rules and procedures are (in a limited way) also relevant to other (non-state, specialist-focused) archives and can serve them by providing a possible model of good practice (see Appendix 2, Table 1).

\section{B. Other topic-specific public qualitative data archive resources}

Among other topic-specific public qualitative data archive resources we list particular data collections (see Appendix 2; Table 2) which do not fall directly under the state archiving policy regulations, although the government of the Republic of Slovenia still provides the main source of their funding ${ }^{11}$. They are more or less autonomous and are independently managed by scientific, education or information institutes such as institutes or museums that run under special government licence.

These independent public qualitative data resources share distinct competencies and are preserving material in their specific area of activities, covering substantive areas of interest. They follow their own idiosyncratic ${ }^{12}$ archiving rules based on their specialised subjects. Each of them holds their own original subject-specific evidence, in subject-specific formats, for subject-specific use (primarily social and biographical historians, or the general public at occasional exhibitions).

For example, the archives of Slovenian Radio and Television (RTVSLO) can be seen as a very rich and relevant source of qualitative data. This archive does not fall under the same policy rules as the national archives, but is otherwise systematically well-organised, preserving video and audio materials of all the TV production broadcast on Slovenian national radio and television. The accessibility of these multimedia materials is not under any strict rules and much of the national radio and television broadcast is directly accessible through their Internet multimedia archive centre, while an advanced search engine within the video content is under development but can be tested online ${ }^{13}$.

Among relevant organized initiatives of archiving of national heritage on the state side three other projects of digitization of national cultural heritage supported by the Ministry of Culture must be mentioned ${ }^{14}$ : DLIB - Digital Library of Slovenia is part of the National and University Library (NUK), KAMRA - Digitalised cultural heritage of Slovenian regions and SISTORY - digitization of Slovenian historical literature and historical sources as part of Slovenian cultural heritage. SISTORY is managed by the Institute for Contemporary History in Ljubljana and takes the form of a database available for the whole research community, with historians as the primary users. It also takes part in DARIAH - Digital Research Infrastructure for the Arts and Humanities which tries to provide a coordinated infrastructure for supporting preservation of cultural heritage in Europe (Lazarević and Vodopivec, 2007). DLIB is probably also the place for a future Internet archive.

\section{Archiving infrastructure for preserving the production of qualitative data originating from social science research projects}

This section explores qualitative data archiving facilities that are especially devoted to preservation of qualitative data from social science research projects. These do not cover the artefacts relevant for Slovenian national heritage, but rather all independently produced qualitative data sources emerging from public, academic or scientific research initiatives.

First attempts of practice in archiving special, research-oriented qualitative data collections can be noted at the Department for Ethnology and Cultural Anthropology at the University of Ljubljana by a project, ETNOINFOLAB, which strives to organise and centralise the department's documentation service system (including all qualitative data collected by the students during their study or by researchers working at the institute) and provide the available qualitative data sources for its staff and interested researchers as well as the wider public, over a single computer system together with applications for data storage and re-use.

These are small in scale and are managed and financed autonomously by the research institutes alone, following their own particular and idiosyncratic qualitative data archiving rules. They hold rather limited numbers of qualitative data collections as they are still in the process of developing the proper qualitative data archiving and sharing infrastructure: mainly they contain ethnographic research materials (transcripts of interviews, copies of photographs) and limited amounts of other diverse data formats resulting from qualitative social science research. Re-use of these data is in general limited to a closed circle of academic researchers (most commonly used by students and professors for teaching).

Social Science Data Archives (ADP - Arhiv Družboslovnih Podatkov) $)^{15}$, as the main quantitative data repository in Slovenia, endeavours to extend its services more intensively into the qualitative domain: it is already holding data from a few qualitative studies and plans to broaden its activities in this direction. The analogous processes for quantitative data are used for qualitative data. Digitised primary research material of a qualitative study, at this time limited to textual data, is preserved as is raw data in quantitative studies. Studies are catalogued using the Data Documentation Initiative metadata standard $(D D I)^{16}$ for study description. Terminology used is method specific e.g. when describing kind of data and research instrument used. ADP is subsidized by ARRS long-term research infrastructure grant. Its mission is to be responsive to the demands of the general social science research community both nationally and internationally. It has been under development for more than ten years, and has thus acquired extensive professional knowledge on data archiving rules upon which to build its services. It offers data free for scientific and educational purposes and uses internationally recognised standards and procedures in acquiring, preserving and disseminating the data. It is also a member of international organisations and partners in their projects (Council of European Social Science Data Archives (CESSDA), International Federation of Data Organizations (IFDO)). These attempts have the potential for establishing the foundation for a genuine qualitative data infrastructure upon which to build in the future.

While only these two facilities are already active in providing qualitative data sources for reuse (either in electronic or hard copy), there are also several other existing public (qualitative research oriented) organisations generating an important amount of qualitative data without any form of systematic preservation. These are listed in Appendix 2 as a relevant source of qualitative data to be potentially integrated into a proper qualitative data archiving infrastructure in the future.

\section{Private archives or facilities for preservation of qualitative data of private research agencies}

The remaining category in our classification is another important source of qualitative data production: private research organisations 
such as marketing research agencies, advertising companies, or public relations offices. They produce a mass of ad-hoc qualitative studies generating a large quantity of data without any real consideration for its integral, systematic and organised preservation which would enable its later re-use. Despite the existing legal framework for its establishment, we have not found any evidence of private venture activities for qualitative data archiving ${ }^{17}$ that would enable data to be shared more widely. The main reasons for this are always given as personal privacy protection laws and the problem of property rights of the data, which belong to private companies that are not willing to share what is often perceived as confidential business data (ARGON, MEMO), even if examples exist of quantitative data from private sector, stored in ADP. Some private research agencies (ARAGON, for example, from 2008 onwards) have started to build their own private data archives, systematically preserving all the data originating from quantitative as well as qualitative studies conducted by them. However, these data sources in any case remain unavailable for further exploitation by external users. The majority of qualitative data sources originating from the private sector, which are rich in content, diverse in formats and large in number (but of variable quality) now remain dispersed without any central node for their coordination, preservation and potential reuse.

\section{Qualitative longitudinal data in Slovenia}

By their nature, the majority of state managed and specialist archives of qualitative data that are concerned with the preservation of Slovenian culture are by definition longitudinal. This type of qualitative data indirectly addresses social temporality in terms of bearing witness to its time.

For example, since 2003, a Museum of Contemporary History (Kokalj Kočevar, 2005) is systematically collecting oral life stories and memories (in video and audio formats) about 20th century Slovenian history (the project is mainly aimed at capturing the period of the first and second World Wars). Some of these materials are already accessible to the public, in digital format and directly over the internet, for example Mojazgodba, www.radio.ognjisce.si and www.ushmm.org/research/ collections/oralhistory/search.

As another example, the Sistory project ${ }^{18}$ was launched at the Institute for Contemporary History to provide a coordinated infrastructure for supporting preservation and sharing of national cultural heritage (Lazarević and Vodopivec, 2007). Relevant national historical documents are becoming widely available from a single common access point for the research community at large. The information system allows for browsing or searching for scientific papers, reports and discussions published in Slovenian historical publications (printed and electronic) on various periods of Slovenian history. There is also open access to some of the historical databases containing visual materials and maps. A similar recent project that issued a public call for lay memories of Tito's funeral promises to archive the material collected ${ }^{19}$.

On the other hand, these are not conceptually designed, longitudinal data that would have resulted from problem-oriented, qualitative research studies directly addressing time, temporality, or prospectively tracking changes over time. In the area of originally produced data by social science research from the autonomous social science or private research organisations described above, we are aware of two longitudinal infrastructures for the management and re-use of longitudinal data. These are the already mentioned Social Science Data Archives and ETNOINFOLAB, the first holds mainly quantitative data sources, some of which are longitudinal.
ADP holds numerous repeated cross-section studies (time use studies, media use studies, social values studies), some of which are in the form of internationally harmonised, continuous longitudinal datasets ${ }^{20}$ Occasionally there are minor follow-ups on the same sample ${ }^{21}$. Finally there are also limited panel or continuous cross-section data available $e^{22}$ However, ADP does not hold data from any kind of qualitative longitudinal study.

Something close to qualitative longitudinal data can be found in the archiving infrastructure of the ETNOINFOLAB documentation service, provided by the Department of Ethnology and Social Anthropology at the Faculty of Arts - UL. ETNOINFOLAB (Ethnographic Information Laboratory) started in 2006 as the project for systematically regulated digitization of extant ethnographic data collections and their integration into a single common database, mainly comprising interviews (voice transcriptions in text format) with accompanying photos. The collections cover topics that range from material, social and spiritual culture in Slovenia as reflected in the everyday life of individuals, and encompassing the time period from the 19th century until the present day. The most important collections in ETNOINFOLAB were created by:

- $\quad$ Ivan Benigar, a South American Anthropologist working among the Mapuce Indians in Patagonia, Argentina;

- Joel M. Halpern, a prominent American cultural

anthropologist who has conducted community studies in two Slovenian villages;

- Vekoslav Kremenšek (1930) and Vilko Novak (1910-2002),

who have conducted locality and economic migration studies in Slovenia.

Further details of these important qualitative longitudinal resources are listed in the appendix and on the web ${ }^{23}$.

All of these qualitative longitudinal data collections are already available via ETNOINFOLAB documentation and information service. Since August 2008 all the collections are listed on the Internet in detail, and many digitised images of original documents, field notes and photographic material are freely available for public use ${ }^{24}$. In addition, ETNOINFOLAB and its electronic information service provide students with practical knowledge and skills to use the necessary computer applications, as well as processing techniques for data, sound, and film.

Outside of the ETNOINFOLAB only occasional individual research projects involving qualitative longitudinal data were identified such as a small scale student research project collecting family genealogy histories is currently ongoing at the Faculty of Social Sciences as a part of the study process, but its results are still uncertain ${ }^{25}$. Such dispersed individual research projects based on the collection of longitudinal qualitative data are obviously not yet a part of any of the archiving infrastructures mentioned above, but should in any case be kept in mind for future development of this particular area.

\section{Development and planning}

Two major problems in qualitative data resources in Slovenia have been identified: a general lack of qualitative longitudinal resources and missing infrastructure for archiving the existing qualitative data resources originating from independent research projects conducted by public and private organisations. The main reasons for such a situation can be found in the rather low value attached to qualitative research data in Slovenia in general, and a low level of awareness of the potential of data archiving and sharing that prevails within the research community. Also, in general there is a very low level of 
knowledge about what qualitative data is available and what can be counted as data archiving infrastructure facilities.

\section{Identified problems and gaps:}

- An important reason for the limited systematic organisation of qualitative data resources are, above all, ethical concerns, as is often emphasised by data producers (FSD, ARAGON, MEMO, and FDV). The consent forms used for participation in qualitative research normally allow use of primary research materials for the sole purpose of generating reports for the particular research case, and prohibiting exposure of personal information that may identify individual participants. It is believed (wrongly) that these conditions automatically preclude making the original research materials available to others: strong doubts persist that even with very sophisticated qualitative data manipulation, anonymity could not be achieved for the purpose of privacy protection for the original research material that might be shared. This is one area where established institutions could provide best practice guides and training for researchers to start thinking about data archiving early in project conceptualisation in order to remove any ethical or legal obstacles for future re-use ${ }^{26}$.

- Another reason for resistance to sharing may be found in a tendency toward monopolisation of original research material for the advantage of the primary researcher or agency, which is again in tension with a data sharing. In the case of private (marketing) research companies, which are likely to represent one of the largest resources of qualitative data, the research material is legally owned by the company paying for the research, which makes data sharing even more complicated. Agencies conducting this research have little motivation to resolve such complications to enable sharing.

\footnotetext{
- An additional problem facing a stronger qualitative data sharing initiative is anchored in the lack of knowledge and professional sound practice among active researchers of how to deal with the task of organising, managing, archiving and sharing data. Despite the availability of data, procedures for archiving are not wellspecified and therefore challenging to fulfil. A main obstacle for qualitative data archiving is often simple lack of human resources in the research organisations where there is often very little administrative support for research activities, such as, for example, data preservation after the completion of a project.
}

\section{- Researchers working alone or in small teams do not tend to} engage in data preservation activities as they lack the motivation and often the time for such work. Archiving is unfortunately not perceived as an activity that has the same level of academic prestige and relevance to professional identity as conducting primary research. There is currently no clear professional track of rewarding archiving activities, and people with the capacity to pursue academic careers don't take enough interest in it.

There are also institutional barriers to the development of more dedicated, specialised social science qualitative data archiving infrastructures. For example, existing infrastructures and networks around qualitative research that are centralised at the University of Ljubljana (by far the largest academic institution in the country) were not perceived to be effective enough for taking over the task of archiving. In discussions, it was mentioned that there is a need for stronger coordination and networking of data infrastructures in an interdisciplinary fashion, but currently there is no real interest in such an initiative. ADP was often considered as an institution that could be asked for support by data producers in the past (FSD), but no further steps were taken in the direction of establishing any formal contract.

Considering the state of archiving and sharing of qualitative data resources in the future there is a need to work on the following development priorities:

- Promotion of the idea of qualitative longitudinal data collection and raising the awareness of the value and benefits of qualitative data archiving and sharing. One possible step in this direction is ADP's organisation of seminars setting out the important aspects of data archiving as part of the research process, and providing an overview of guidelines for efficient data archiving. For this to take place the collaboration of research organisations is required!

- Establishment of a formal appraisal and selection policy that would reflect the future re-use potential of qualitative research material compared to the cost of production, preservation and access. A detailed methodological description of the research process itself should be always undertaken to allow for judgement of data quality for this purpose. It can be estimated that only a limited number of the most valuable qualitative studies (up to 5 per year) would qualify for archiving in ADP. Those remaining could be deposited in a general public research digital repository such as DLIB.

- Preparing a package of procedures for consistent qualitative data archiving, specially dedicated to preserving original materials from autonomous qualitative research projects, taking into account ethical considerations and international standards. This will be available on demand for research organisations to help them organise and preserve their future qualitative research projects throughout the data life-cycle. IASSIST (International Association for Social Science Information Services \& Technology) and CESSDA assistance is required for advising on qualitative data archiving regulations, guidelines and standards ${ }^{27}$.

Trying to develop a motivation scheme as well as formal requirements to be set out for research organisations and individual researchers to systematically report and organise their qualitative data materials for the possibility of being included in the larger infrastructure for qualitative data archiving. For example, this would include introducing additional scientific criteria that would properly value and reward archiving activities in terms of academic careers. This would require further changes in established institutional rules.

- Acquiring specialisation of human resources in qualitative data archiving within existing ADP. This would require devoting a post for qualitative data resource management, as a point of reference and advice, as well as practical support and management of existing qualitative data from various sources. Additional funding would be required.

\footnotetext{
- Taking a first step towards coordination of dispersed producers and sources of qualitative data by moving towards establishing a common catalogue of all the existing qualitative data materials publicly available. This should slowly lead to general rationalisation of national qualitative archiving activities and step-by-step establishment of a general single point of access to all qualitative data resources. A set of common standards and rules should be agreed upon to achieve inter-operability and professional soundness of the whole endeavour.
} 


\section{CONCLUSION: How might existing organisations be of assistance?}

Support for professionalization and training in the field of qualitative data archiving is needed. The usefulness of ESDS Qualidata training and support materials is already recognised as a baseline for international integration of activities in the realm of qualitative data archiving and sharing. Establishing a stronger organisational foundation within CESSDA could strengthen support for members and spread good practice, e.g. in how to fill in gaps in collections in particular countries, by enabling visits and mentoring facilities in development of new services, and advice and training for researchers and archivists. In particular, the support from the international organisations would be important in the following areas:

\footnotetext{
- Internationally coordinated fund raising and country research policy formulation activities, e.g. inclusion of CESSDA and DARIAH projects in the future ESFRI (the European Strategy Forum on Research Infrastructures ) funding scheme.

- Development of professional profiles and establishment of training schemes to build expertise for qualitative archiving, data sharing and its re-use in terms of secondary analysis.

Synchronisation of common activities for development of needed tools and processes that would support qualitative archiving and sharing

- Development of common standards and training in their use (e.g. a DDI "lite" template suited for qualitative data).

- Establishment of harmonised rules based on established protocols and preservation policies that effectively guarantee the long-term access to qualitative data resources.
}

Extension of the role of ADP is often mentioned as one of the best solutions for preservation and sharing of the valuable qualitative data produced by these research centres (FDV, FSD). ADP is the only science data archiving infrastructure in the country, with a well-established repository of data mainly from large-scale social surveys. As such it has a solid foundation from which to broaden its service to qualitative data archiving in the future. However, its existing data deposit system and data sharing regulations should be properly extended for qualitative data archiving ${ }^{28}$. In this way ADP could serve as a possible node, with experiences and existing resources in the area of quantitative data, which could be extended or adapted for the special needs of qualitative data, and for building a centrally integrated mixed-methods social science data archive.

An alternative for preservation of these dispersed qualitative data sources is their integration into existing the ETNOINFOLAB service of ethnographic documentation system. Each solution has its benefits. In the first case, a single access point to mixed types of data in the form of a common and centrally coordinated management system for archiving and sharing qualitative and quantitative data that can be reused for any purpose can be seen as an advantage. In the second case the existing qualitative data might be simpler to integrate into already established information systems, thus avoiding the problem of bridging quantitative and qualitative data storage standards. This may result in easier implementation as well as faster service provision to the end users. Closer familiarity with the substance and format of data could be an advantage for this latter option.

In any case these do not need to be mutually exclusive alternatives. Cross-overs between the systems, harmonisation and co-ordination of activities would serve best the common interests. As it is not expected to anticipate an abundance of human and financial resources, all those willing to spend their energy in establishing an expanded Slovene Qualidata service would be welcomed.

\section{References}

Kokalj Kočevar, M. (2005). 'Time in memory: Lived experience; what is remembered and what is forgotten' In: Adding of memories of WW2, Using the war: Changing memories of WW2. Annual conference of the OHS: London

Lazarević, Ž. and Vodopivec, N. (2007). (Inštitut za novejšo zgodovino/ Institute for Recent History, Ljubljana), 2007, Beograd, Sistory: digitalizacija istorijskih sadržaja (Sistory: digitization of historical sources), Преглед НЦД 11, 31-36.

OECD. (2007)). 'OECD Principles and Guidelines for Access to Research Data from Public Funding' [Online]. Available at:

http://www.oecd.org/dataoecd/9/61/38500813.pdf [Accessed 12th March 2010]

Žumer, V. (2001). Arhivi v RS - Zakladnica virov za rodoslovna raziskovanja. Drevesa : bilten slovenskih rodoslovcev ISSN: 1318-6221.- Vol. 8, No. 3 (2001), str. 29-35. [Online]Available at: http://www2.arnes. si/ krsrd1/conference/Speeches/Zumer_ARS_rodoslovje.htm

\section{Appendix 1:}

List of other individuals, organisations and their abbreviations for the purpose of the report

- ETNOINFOLAB

HUDELJA, Mihaela, documentalist ETNOINFOLAB

Oddelek za etnologijo in kulturno antropologijo FF (Department for ethnology and cultural anthropology, Faculty of arts, University of Ljubljana)

e-mail: mihaela.hudelja@ff.uni-lj.si

internet: http://etnologija.etnoinfolab.org/en/default.asp

\section{- MNZ-SI}

KOKALJ KOČEVAR Monika, MA, Museum Adviser

Muzej novejše zgodovine Slovenije / National Museum of

Contemporary History (MNZ-SI)

e-mail: monika@muzej-nz.si

interent: http://www.muzej-nz.si/

- FSD

RIHTER Liljana, PhD, Senior Lecturer

Fakulteta za socalno delo / Faculty of social work, University of

Ljubljana (FSD)

e-mail: liljana.rihter@fsd.uni-lj.si

internet: http://www.fsd.si/faculty_and_staff/2008050813072178/

- MEMO

PERČIČ Eva, Ma, Research director, MEMO

MEMO Institute - Creative Research d.o.o.

e-mail: eva.percic@memo.si

internet: http://www.memo.si/index.php

\section{- ARAGON}

PREŠEREN Jana

Aragon, d.o.o., research and planning

e-mail: Jana.Preseren@aragon.si

internet: http://www.aragon.si/eng/ 
- FDV

TIVADAR Blanka, PhD, and KAMIN Tanja, PhD

Center for research on social psychology, Institute of Social Sciences, Faculty of Social Sciences, University of Ljubljana (FDV)

e-mail:Tanja.Kamin@fdv.uni-lj.si; blanka.tivadar@guest.arnes.si Internet: http://www.fdv.uni-lj.si/English/Research/Research_c. asp?id=11 http://csp.fdv.si/

ADAM Frane, PhD

Faculty of Social Sciences, University of Ljubljana

e-mail: frane.adam@fdv.uni-lj.si

internet: http://www.fdv.uni-lj.si/Kontakti/osebne.asp?id=1

\section{Appendix 2 (Žumer, 2001)}

\section{Table 1: List of Slovenian state Archives holding remains of national heritage}

\section{Arhiv Republike Slovenije (Archives of the Republic of Slovenia)}

Address: Zvezdarska 1, 1127 LJUBLJANA, p.p. 21

Phone: (01) 2414 200, (01) 2414250

Fax: (01) 2414269

e-mail: ars@gov.si

Internet: http://arhiv.gov.si/

NOTE: Slovene Film Archives keeps Slovene documentary films, cartoons and feature films from 1905 (when the oldest Slovene film was made) onwards. More than $90 \%$ of all Slovene films or 5,100 titles are preserved.

\section{Zgodovinski arhiv Ljubljana (Ljubljana history archive)}

Address: Mestni trg 27, 1000 Ljubljana

Phone: (01) 3061306

Fax: (01)42 64303

e-mail: zal@zal-lj.si

Internet: http://www.zal-lj.si

\section{Pokrajinski arhiv Koper (Koper province archive)}

Address: Goriška 6, 6000 Koper

Phone: (05) 6271824

Fax: (05) 6272441

e-mail: arhiv.koper@guest.arnes.si

Internet: http://www.arhiv-koper.si/

\section{Pokrajinski arhiv Maribor (Maribor province archive)}

Address: Goriška 6, 6000 Koper

Phone: (05) 6271824

Fax: (05) 6272441

e-mail: slavica.tovsak@pokarh-mb.si

Internet: http://www.pokarh-mb.si/

Pokrajinski arhiv Nova Gorica (Nova Gorica province archive), Address: Trg E. Kardelja 3, 5000 Nova Gorica

Phone: (05) 3027737

Fax: (05) 302773

e-mail: pang@guest.neticom.si

Internet: http://www.pa-ng.si
Zgodovinski arhiv Ptuj (Ptuj history archive)

Address: Muzejski trg 1, 2250 Ptuj

Phone: (02) 7879730

Fax: (02) 7879740

e-mail: Zgod.arhiv-Ptuj@guest.arnes.si

Internet: http://www.arhiv-ptuj.si/

\section{Table 2: Topic-specific public infrastructure of qualitative data} resources

Zgodovinski arhiv in muzej Univerze v Ljubljani (History archive and museum of University of Ljubljana)

Address: Kongresni trg 12, 1000 Ljubljana

Phone: (01) 4254055

Fax: (01) 4254053

e-mail: info@uni-lj.si

Internet: http://www.uni-lj.si/o_univerzi_v_ljubljani/univerzitetni_arhiv/ amsu.aspx

NOTE: documentation about the work, life and function of University of Ljubljana

\section{Dokumentacija RTV Slovenija (Documentations of Slovenian national Radio and Television)}

Address: Kolodvorska 2, 1000 Ljubljana

Phone: (01) 4753616

Fax:

e-mail: tvdokumentacija@rtvslo.si

Internet: http://www.rtvslo.si/modload.

php?\&c_mod=static\&c_menu=1053436918

NOTE: audio and video material of Slovenian national television production in electronic form

\section{Narodna in univerzitetna knjižnica - Rokopisni oddelek (National} and university library - manuscript division)

Address: Turjaška 1, 1000 Ljubljana,

Phone: (01) 2001110

Fax: (01) 4257293

e-mail: uprava@nuk.uni-lj.si

Internet: http://www.kud-logos.si/ROKOPISI/rokopisni-anglesko.htm NOTE: central national and state-owned collection of original manuscript material from the fields of literature, linguistics and broader humanities dating back to 1774 (available on microfilm, paper, photographic and digital copies);

Narodna in univerzitetna knjižnica - Digitalna knjižnica Slovenije (National and university library - The digital library of Slovenia) Address: Turjaška 1, 1000 Ljubljana,

Phone: (01) 2001167

Fax: (01) 4257293

e-mail: dlib.si@nuk.uni-lj.si

Internet: http://www.dlib.si/

NOTE: a web portal providing ready access to Slovenian knowledge and cultural treasures with offering free searching of text (books, periodicals), visual (photos, maps) and sound resources with respect to Slovenian cultural heritage; new project under development: building a complete archives of Slovenian (electronic) documents on the world wide web. 
Arhivi Katoliške cerkve (Archives of Catholic Church)

Address: Krekov trg 1, 1000 Ljubljana

Phone: (01) 4337044

Fax: (01) 4396435

e-mail: arhiv.lj@rkc.si

Internet: http://lj.rkc.si/?id=11\&fmod=2

NOTE: valuable historical collection of books with birth recordings; important for genealogy research

\section{Muzej novejše zgodovine Slovenije (National Museum of} Contemporary History)

Celovška 23, 1000 Ljubljana

Tel. 0038613009637

Fax. 0038614338244

e-mail: info@muzej-nz.si

Internet: www.ushmm.org/research/collections/oralhistory/search NOTE: huge collections of life stories and memories (in video and audio format) on 20th century history (focus on first and second world war).

\section{Muzej novejše zgodovine Celje (Museum of Recent History} in Celje)

Prešernova ulica 17, 3000 CELJE

tel.: +38634286410

fax: +38634286411

E-mail: mnzc(at)guest.arnes.si

Internet: www.muzej-nz-ce.si

NOTE: huge collection of audio and video documentation about craft and craftsmanship in Celje, their life stories, etc.

Inštitut za novejšo zgodovino (Institute for Recent history)

Kongresni trg 1,1000 LJUBLJANA

Phone: +38612003120

Fax: +38612003160

E-mail: info@inz.si

Internet: www.sistory.si/

NOTE: large and rich internet based electronic service point of historical sources in Slovenia; total access to print and archive sources, databases, visual material and maps.

Table 3: Archives of originally produced qualitative data originating from autonomous social science research projects

ETNOINFOLAB - Oddelek za etnologijo in kulturno antropologijo FF (Department for ethnology and cultural anthropology, Faculty of art)

Address: Zavetiška 5, 1000 Ljubljana

Phone: 0038612411520

Internet: http://www.etnoinfolab.org/

NOTE: valuable and rich ethnographic data collections (interviews, photos) collected by the members and students of the Department during their research and pedagogic activity dating back to 1956. National territory of Slovenia, Austria, Italy, and Hungary, as well as the republics of the former Yugoslavia and some other parts of Balkan are covered.
ADP - Arhiv družboslovnih podatkov (Social science data archives, Faculty of Social sciences, University of Ljubljana)

Address: Kardeljeva ploščad 5, 1000 Ljubljana

Phone: (01) 5805292

Fax: (01) 5805294

e-mail: arhiv.podatkov@fdv.uni-lj.si

Internet: http://www.adp.fdv.uni-lj.si/

NOTE: preserving a few (around 10) subject specific qualitative studies that are not survey or statistical data originating from autonomous research projects

Table 4: Important research centres as producers of qualitative data without the infrastructure for its preservation

Institututum Studiorum Humanitatis - Faculty for postgraduate studies in humanities

Address: Slovenska cesta 30a, 1000 Ljubljana

Phone: + 38614251845

Fax: + 38614251846

e-mail: ish@ish.si

Internet: http://www.ish.si/en/

\section{Scientific Research Centre of the Slovenian Academy of Sciences} and Arts

Address: Slovenska cesta 30a, 1000 Ljubljana

Phone: 3861 470-6-100

Fax: 3861 425-52-53

e-mail: zrc@zrc-sazu.si

Internet: http://odmev.zrc-sazu.si/zrc/

Peace Institute - Institute for contemporary social and political studies

Address: Metelkova 6, 1000 Ljubljana

Phone: + 38612347720

Fax: + 38612347721

e-mail: info@mirovni-institut.si

Internet: http://www.mirovni-institut.si/Main/Index/en/

University of Ljubljana - Faculty of social work (delinquency, youth, and mental health)

Address: Topniška 31, 1000 Ljubljana

Phone: +38612809240

Fax: +38612809 270

e-mail: info@fsd.uni-lj.si

Internet: http://www.fsd.si/eng/

University of Ljubljana - Institute of Social Sciences

Address: Kardeljeva ploščad 5, 1000 Ljubljana

Phone: + 386015805200

Fax: + 386015805213

e-mail: fdv.idv(at)fdv.uni-lj.si

see in particular (Internet):

Center for research on social psychology (contemporary ethnology of everyday life) [http://csp.fdv.si/; http://www.fdv.uni-lj.si/English/ Research/Research_c.asp?id=11]

Social Communication Research Centre (media content studies) [http://www.fdv.uni-lj.si/English/Research/Research_c.asp?id=7]

Centre for Spatial Sociology (remains of large scale qualitative studies conduced by prof. Zdravko Mlinar, now retired) [http://www.fdv.unilj.si/English/Research/Research_c.asp?id=14] 
Centre for methodology and informatics (meta analysis of qualitative studies) [http://english.fdvinfo.net/index.php?fl=0\&p1=300\&p2=301 \&p3=\&id $=103$ ]

\section{Appendix 3: Qualitative Longitudinal Resources in Slovenia}

Important cultural historical studies held in ETNOINFOLAB

- Ivan (Juan) Benigar (1883-1950): a famous Slovene anthropologist who lived in South America among Indians Mapuče in Patagony (Argentina) for more than 40 years and became one of the best known anthropologists in South America. The collections of his work consist of digital copies of hundreds of pages of all of his field notes, excerpts and different kinds of manuscripts that relate to his research work.

- Joel M. Halperen (1929): Halpern, a prominent American cultural anthropologist who has worked as a field researcher in Slovenia in the period of 1962/63, has gathered field data covering two Slovenian villages (Šenčur and Gradenc) that consists of field notes (more than 2000 pages of typescript) and more than 1000 photos and slides of everyday social life.

- Vekoslav Kremenšek (1930) and Vilko Novak (1910-2002), in doing extensive research projects with their students, have gathered a huge collections of data covering the following area and time period:

- Collection ETSEO / Ethnological topography of Slovene ethnic territory. 1975-90

- Collection Galjevica (Urban suburb of Ljubljana). 1970-75

- Collection Vitanje. 1975-80

- Collection Izseljenstvo (economic emigration from Slovenia)

\section{Notes}

1.Contact details of country reporters:

The country report on qualitative data resources for Slovenia was written by the following team of experts, each of them covering a particular area of the field under investigation.

\section{Janez Štebe}

Area: national policies, data archiving and sharing procedures, quantitative and qualitative research resources, development policies, IASSIST and CESSDA assistance

University of Ljubljana - Social Science Data Archives [http://www.adp. fdv.uni-lj.si]

Kardeljeva ploscad 5, 1000 Ljubljana

[janez.stebe@fdv.uni-lj.si]

\section{Jože Hudales}

Area: ethnographic qualitative data resources, qualitative data in museums, qualitative longitudinal data

University of Ljubljana - Faculty of arts, Department for ethnology and social anthropology [http://etnologija.etnoinfolab.org/en/default.asp] Askerceva 2, 1000 Ljubljana

[joze.hudales@ff.uni-lj.si]

\section{Boris Kragel}

Area: state archives with national cultural heritage, private and public qualitative resources

University of Ljubljana - Faculty of social sciences

[http://www.fdv.uni-lj.si/English/Office_IC/

Kardeljeva ploscad 5, 1000 Ljubljana

[boris.kragelj@fdv.uni-lj.si]
2. The report reflects the particular institutional background of the reporters: it mainly builds upon the circumstances of (predominantly quantitative) data archiving at Social Science Data Archives of Slovenia (ADP), that covers broad domain of social sciences in a country, supplemented with the perspective from a more humanities oriented domain, covered by Department of Ethnology and Social Anthropology of the Faculty of Arts at University of Ljubljana (FF). In addition, to survey overall existing qualitative data resources and collect the relevant information about the general situation concerning the data sharing and data archiving culture, a number of research groups and organisations with qualitative research profiles were briefed, either orally or in writing (a complete list of external collaborators involved in the preparation of the report is presented in the Appendix 1). Among all surveyed qualitative research centres, the following in particular proved to be valuable for the information presented in the final report: Faculty of Social Work (FSD) with its long and well established tradition of qualitative research on delinquency, youth, and mental health; The National Archives of the Republic of Slovenia (ARS), a preeminent institution for systematic preservation of historical national heritage concerning the Slovenian state, and The National Museum of Contemporary History (MNZ), a state museum, which provides a central public service in the area of the movable heritage of contemporary history, preserving studying and communicating the material and non-material heritage in the sphere of the history of the Slovene ethnic space from the beginning of the 20th century.

3. For further information see, http://www.arrs.gov.si/en/

4. See, http://www.mvzt.gov.si/en/,

5. For more information on the collections, policies, procedures and laws guiding and regulating the archiving and sharing of these materials see national Archives of the Republic of Slovenia - Ministry for Culture [http://www.arhiv.gov.si/en/].

6. Some descriptive metadata is usually presented in the final research report alone and not prepared as an independent report accompanying raw data (FSD, FDV).

7. See list in appendix 2.

8. For further information see, http://www.arhiv.gov.si/

si/e_hramba_dokumentarnega_gradiva/.

9. See http://arsq.gov.si/Query/suchinfo.aspx

10. For further information see http://www.arhiv.gov.si/si/ zakonodaja_standardi_in_dokumenti/.

11. The only obvious exception is Archive of the Catholic Church.

12. See, www.rtvslo.si

13. See http://www.rtvslo.si/odprtikop/

14. Weblinks for other projects of digitization of national cultural heritage supported by the Ministry of Culture, see http:/www.dlib.si/; http:/www.kamra.si/; http:/www.sistory.si/; http://www.dariah.eu/

15. See http://www.adp.fdv.uni-lj.si/

16. See http://www.ddialliance.org/

17. Archives of the Catholic Church can be seen as the exception

18. See www.sistory.s

19. See http://www.tovaris-tito.si/, accessed on 1.3.2010.

20. For an example of an event history data study, see LOL94 - http:// www.adp.fdv.uni-lj.si/opisi/lol94/

21. For example, pre- and post-election re-interviews: SJM90 - http:// www.adp.fdv.uni-lj.si/opisi/sjm90/

22. For example, Slovene Labour Force Survey - http://www.adp.fdv. uni-lj.si/opisi/serija/ADS/.

23. For further details see under the heading "Etnološke raziskave slovenskih in drugih kultur" at http://www.etnoinfolab.org/

24. For details see the following internet addresses: [http://www. etnoinfolab.org/; http://etnologija.etnoinfolab.org/s//informacija. 
asp?id_meta_type=75\&id_informacija=199]. The parts of data collections which are still undergoing research or publication are only available through a special information system (http://193.2.104.52/ studsistem/) for students, members of Department and researchers who must get special permission to log in to the system.

25. For further details contact: Prof. Anton Kramberger; FDV: anton. kramberger@fdv.uni-lj.si

26. See e.g. MANAGE AND SHARE DATA section of ESDS - Economic \& Social Research Council. http://www.data-archive.ac.uk/

27. Overcoming a problem of diversity of qualitative research methods resulting in variety of different data forms and their particular formats shows itself as one of the biggest problems for realisation of more systematic preservation of qualitative data.

28. See, http://www.adp.fdv.uni-lj.si/za_uporabnike/ izrocanje_podatkov/ 